Chapter 6

\title{
Biochar Technology for Sustainable Organic Farming
}

\author{
Suarau O. Oshunsanya and OrevaOghene Aliku \\ Additional information is available at the end of the chapter \\ http://dx.doi.org/10.5772/61440
}

\begin{abstract}
The challenge of agricultural land depletion as a result of the pressure driven by the ever-growing population has brought about a renewed focus on the need for sustainable practices in agricultural production. Biochar is the solid carbonaceous product obtained when plant and/or animal biomass is subjected to pyrolysis. This chapter reviews the properties of biochar and its impacts when incorporated into the soil. Relative to its original organic form, this chapter iterates the benefits of biochar as a more sustainable organic approach towards improving agricultural soil qualities and hence crop yield due to its stability and duration in soils for hundreds of years. The impacts of biochar on soil physical, chemical and biological properties through the enhancement of soil nutrient and water-holding capacity, $\mathrm{pH}$, bulk density and stimulation of soil microbial activities are by improving aggregation, porosity, surface area and habitat for soil microbes in biochar-amended soils. It is therefore recommended that biochar be used as soil amendment, especially to a degraded soil for a large and long-term carbon sink restoration.
\end{abstract}

Keywords: Biochar, Soil chemical properties, Soil water characteristics, Crop yield

\section{Introduction}

Throughout the world, intensive agriculture has often led to decline in soil physical, chemical and biological properties, leading to soil degradation. This decline in soil quality may be due to erosion and mining of nutrients and organic matter, hence preventing the soil from performing its functions such as regulating water flow, storing and cycling of nutrients, filtering, and transformation of organic and inorganic materials and sustaining biological productivity. However, considerably large amount of wastes such as crop residues, animal 
manure, etc. are being produced from many agricultural production systems. This organic waste may represent a considerable problem as well as new challenges and opportunities depending on how they are handled, which may determine whether there will be increase or decrease in biomass production, organic matter supply and decomposition rate.

In addressing the issue of decline in soil fertility, [1] reported that intentional and unintentional deposition of nutrient-rich materials on farmlands have in many cases led to an increase in soil fertility status. However, fresh residue materials have been reported to decompose until almost all carbon is lost [2]. This practice may not be sustainable when compared to the ever-growing human population per time. Thus, conversion of biomass to biochar could alter the transformation dynamics with respect to carbon sequestration. Soil carbon sequestration offers a large and long-term carbon sink to agricultural soils. Biochar is one of the sources of soil carbon sink, which could be obtained by subjecting biomass to pyrolysis. Pyrolysis is a process of combusting organic materials (biomass) under limited oxygen level [3].

Biochar as a soil amendment has become an important topic in soil science in the past few years, and the effects of biochar on agro-ecosystems are being studied by many researchers [4]. The conversion of biomass to bio-char as a carbon sink has been proposed before [5], but was not explicitly linked to an application to soil. As a soil amendment, biochar can greatly influence various soil properties and processes [6]. In fact, biochar may occur as a component of soil organic matter where slash-and-burn agriculture is widely practiced [7]. Many of the organic residues from agriculture, forestry and other production systems can be used to produce biochar and applied to agricultural soil both to sequester carbon and to improve the production potential of crops. This renewed focus in agriculture can be said to have started as a result of the discovery of the Terra Preta de Indo soils (Figure 1) located in the Amazon River Basin. From the assumptions surrounding the formation of the Terra Preta soils, agricultural scientists have come to believe that soil properties could be amended by applying biochar as an amendment [3]. Hence, biochar, the carbon-enriched, fine-grained product of biomass combusted under conditions of limited oxygen, is currently being widely studied for its effects as a soil amendment.

\section{What is Biochar?}

[8] defined biochar as a carbon-enriched, fine-grained and porous by-product of slow pyrolysis when organic material (feedstock) is thermally decomposed at low-moderate temperatures during long heating times under limited supply of oxygen. Feedstock may include wood materials, tree bark, crop residues, chicken litter, dairy manure or sewage sludge. Biochar is chemically and biologically more stable than the original fresh form from which it is produced due to its molecular configuration [9], making it more difficult to breakdown. This means that, in some cases, it can remain stable in soils for hundreds to thousands of years [10]. 

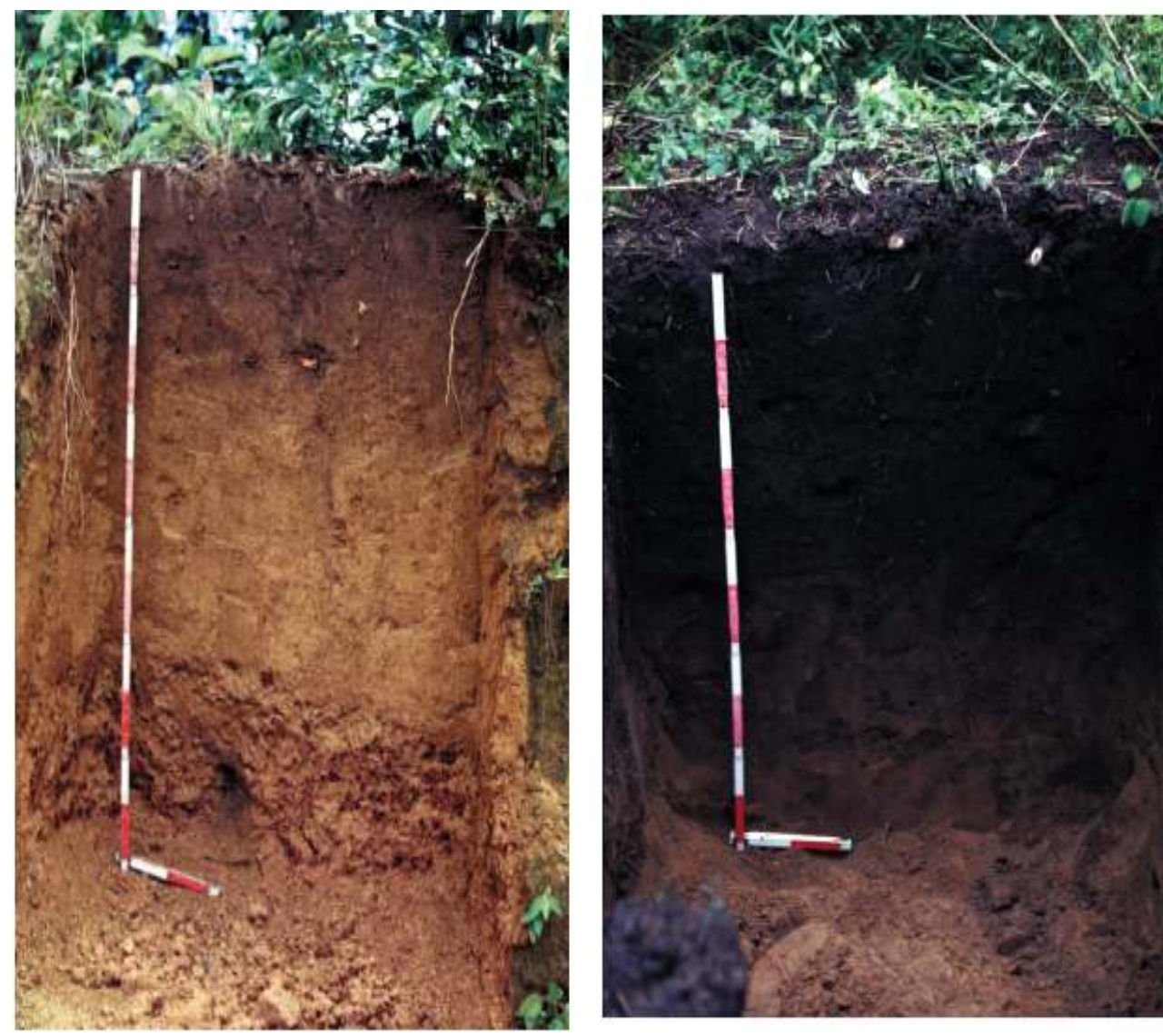

$\theta$

Source: [60]

Figure 1. Pictorial view of Latosol (left) and Terra Preta (right) soil horizon.

\subsection{Properties of biochar}

Biochars are characterized by certain morphological and chemical properties which are borne from the physico-chemical alteration of the original feedstock as a result of pyrolytic process. Characteristically, these properties of biochar differ since they are controlled by factors such as type of organic material from which they are made, pyrolysis conditions (i.e. final pyrolysis temperature or peak temperature, rate of heat application - slow or fast pyrolysis), rate and duration of charring $[11,12,13]$. The impact of biochar as an amendment depends on its properties. Key properties of biochar are the adsorptive properties that potentially alter soil's surface area, pore size distribution, bulk density, water-holding capacity and penetration resistance. Some physical properties of biochar determined by variations in feedstock type and pyrolysis condition are discussed below. 


\subsubsection{Large surface area and presence of micropores}

Large surface area amendment property of biochar contributes to the adsorptive properties of soil and potentially improves pore size distribution, bulk density and consequently leading to an increase in the soil available water needed for crop growth and development. In addition, a strong direct relationship exists between a biochar's surface area and the pore volume as measured using $\mathrm{N}_{2}$ adsorption and Braunauer-Emmett-Teller (BET) modelling [14,15]. [15] reported that the surface area could also be measured by using other compounds such as $\mathrm{CO}_{2}$ on carbonaceous materials at the micrometer scale. [16] stated that understanding and determination of the relative abundance and stability of pores of different sizes are keys to soil ecosystem functioning. Important among these functions are aeration, hydrology and provision of habitat for microbes while the finer pores could be involved with molecular adsorption and transport [17].

Differences in production conditions, especially final combustion temperature, would result to variation in surface area of biochars even when they are produced from the same parent biomass. [16] stated that the relationship between the peak combustion temperature and surface morphological parameters (i.e. surface area, pore diameter and volume) of the resulting biochar is highly complex. [18] stated that there may be either no simple relationship between surface area and peak temperature, or surface area may increase with increase in peak temperature up to a certain threshold and then decrease. Due to variations in reports on surface area and peak temperature, [16] reported that the mechanisms responsible for increases in surface area with an increase in peak temperature or heating rate are not well understood. However, [11] reported that surface area increases with an increase in peak temperature of biochar production.

\subsubsection{Adsorptive property}

The adsorptive nature of biochar is related to its surface area. The adsorptive capability of biochar is determined by its surface chemical properties and porous nature. It is an important physical property due to its influence in the uptake and binding effect of materials from their surroundings [16]. [19] reported that biochar may adsorb poly aromatic compounds, poly aromatic and poly aliphatic hydrocarbons, other toxic chemicals, metals and elements or pollutants in soils, sediments, aerosols and water bodies.

\subsubsection{Stability}

This important physical property makes biochar a more sustainable soil amendment relative to its original fresh biomass for agricultural purpose. The evidence of high amounts of black carbon in the Terra Preta soils over a time suggests a high recalcitrant nature of biochar. However, degradation of at least some components (volatile matter or labile organic matter) of the biochar may occur [20]. On the other hand, [16] noted that the difference in sub-soil characteristics due to variations in microbial activity and oxygen content may affect biochar oxidation and aging. Biochar can move into sub-soil over time [21] to enrich the zone. Hence, other factors associated with its physical stability in soil include its mobility into deeper soil 
profile [16]. The aggregate stability of biochar-amended soil may also determine the susceptibility of biochars to microbial processes in subsoil. Mukherjee and Lal [16] explained that these factors not only enhance the stability of soil organic matter in the deeper profile but also improve availability of water and nutrients to crops and decrease erosion risks.

\section{Restoring/improving soil properties}

Biochar has the potential capacity to restore a degraded soil when added to the soil. Biochar mineralizes gradually over a long period of time when applied to the soil. Nutrients from biochar are released gradually to improve the physical, chemical and biological conditions of the soil. [12] reported that the impact of biochar as an amendment is a function of its properties such as large surface area and presence of micropores. These are key properties because they contribute to the adsorptive properties of soils and potentially alter soil physical and hydrological properties.

\subsection{Biochar and soil properties}

Figure 2 illustrates the interaction between biochar and soil. The application of biochar to the soil will alter the physical and chemical properties of the soil. [22] stated that the net effect of biochar on the soil physical properties will depend on its interaction the physico-chemical characteristics of the soil, the weather conditions prevalent at the particular site and the management of its application. Biochar application can reduce the bulk density of the different soils [23]. This could bring about improvement in soil structure or aggregation, and aeration enhancement, thus improving soil porosity. [17] reported that the higher the total porosity (micro- and macropores) the higher is soil physical quality. This is because micropores are involved in molecular adsorption and transport of water and nutrients while macropores affect aeration and drainage. Several studies have reported that as low as $0.5 \%\left(\mathrm{~g} \mathrm{~g}^{-1}\right)$ biochar application rate was sufficient to improve water-holding capacity and water retention [24,25]. Hence, this can be said to be good water-holding capacity amendment for sandy soils which are highly porous due to the preponderance of macropores.

\subsection{Effect of biochar application on some soil physical properties}

A key determinant of soil functions and processes is its physical properties, precisely and most importantly, its texture. Hence, the addition of biochar in soils with different textures should affect the soil hydraulic properties differently due to the fact that there is a correlation between soil texture and soil hydraulic properties. The impacts of biochar as a soil amendment on some soil physical and hydrological properties are briefly discussed below.

\subsubsection{Soil surface area}

Table 1 depicts a summary of results of biochar application on surface area. Soil surface area is an intrinsic property of soil determined by the sizes of its particles. The surface area of soils 


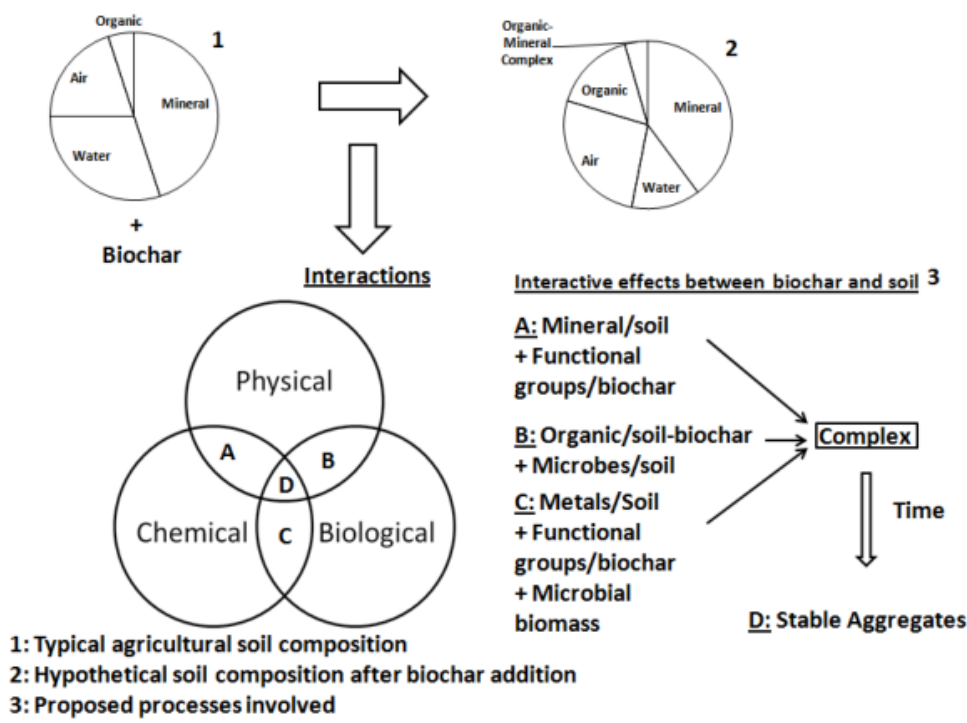

Figure 2. Schematic representation of interactions between biochar and soil [16].

is an important physical characteristic which plays a vital role in water- and nutrient-holding capacities, aeration and microbial activities [26]; hence, it can be said to be partly controlling the essential functions of soil fertility. However, the effectiveness of the surface area of a soil depends on its size - the larger the surface area, the greater the soil's water- and nutrientholding capacities. This is particularly true for fine-textured soils. Thus, [16] reported that agronomic productivity improvement of biochar-amended soils may be linked to the higher surface area of the biochar-soil mixtures. $[17,27,28]$ explained that the high surface area of biochar provides the space for formation of bonds and complexes with cations and anions with metals and elements of soil on its surface, which improves the nutrient retention capacity of soil. [28] reported that biochar incorporation can enhance specific surface area up to 4.8 times that of adjacent soils. [29] also reported increases in specific surface area of an amended clayey soil from 130 to $150 \mathrm{~m}^{2} \mathrm{~g}^{-1}$ when biochar derived from mixed hardwoods was applied at rates of 0 to $20 \mathrm{~g} \mathrm{~kg}^{-1}$ in a long-term soil column incubation study.

\subsubsection{Porosity}

Table 1 shows a summary of results of biochar application on soil porosity. This is the ratio of the pore volume to the total volume of a representative sample of a porous medium. This factor is said to be associated with surface area. The total porosity or pore size distribution of biochar is a factor that can play an important role in the alteration of the properties of biochar-amended soils. Biochars are usually characterized by the preponderance of micropores, which may alter the pore size distribution of coarse texture soil when added. [24] reported that significant increases in mesoporosity occurred at the expense of macropores in waste-derived biochar- 
amended soil compared to the control. [24] further intensified that the higher the rate of biochar application the greater its effect on porosity. Hence, biochar could be a good replacement for tillage practices which causes short-term increase in porosity, but long-term decrease in aggregation and ultimately lowering soil porosity.

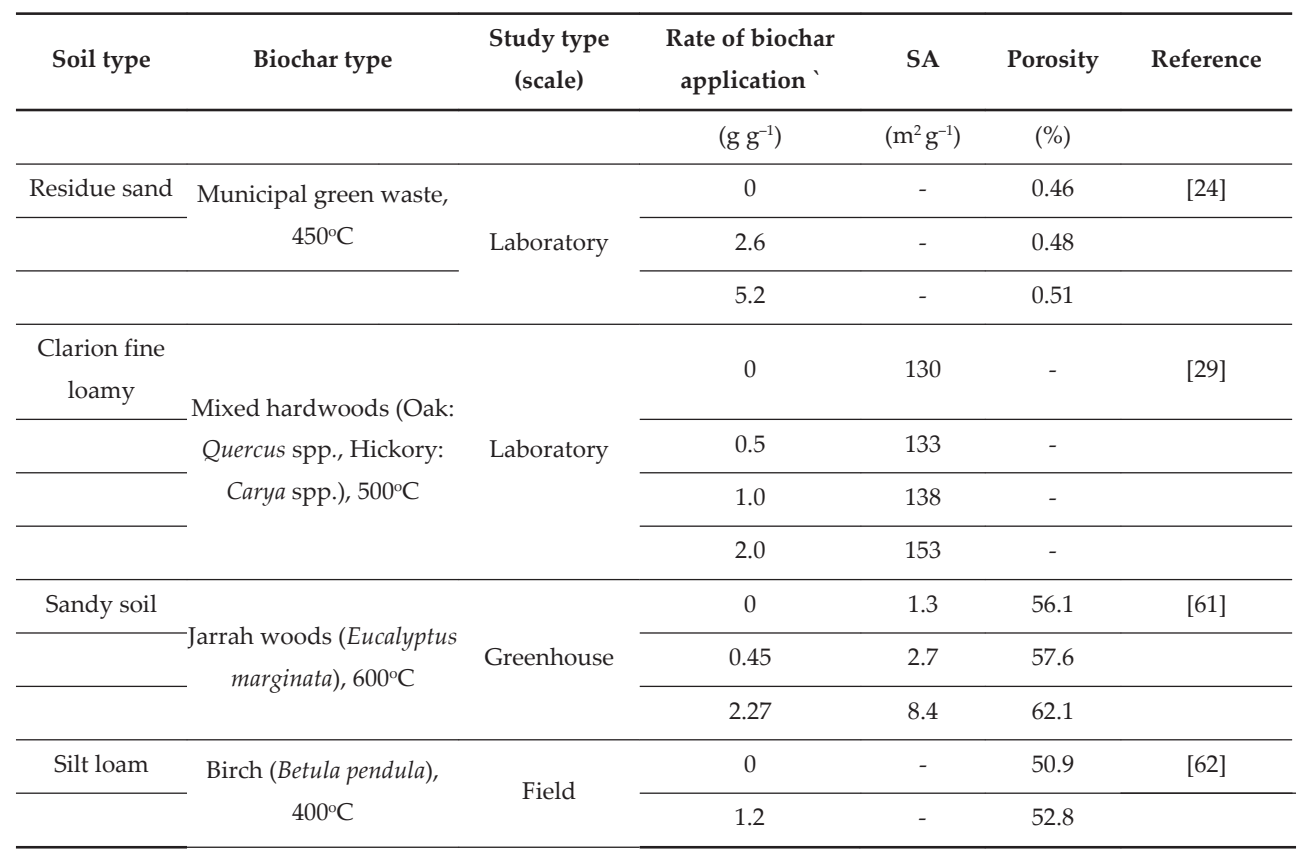

Table 1. Impact of biochar on Surface area (SA) and porosity of amended soils

\subsubsection{Bulk density}

Table 2 shows the results of biochar application on soil bulk density. Bulk density, which is defined as the mass of soil per its unit volume, has been known to have a negative correlation with surface area. [30] stated that well-structured soils (fine texture) are characterized by low bulk density values between 1.0 and $1.3 \mathrm{~g} \mathrm{~cm}^{-3}$ while poorly structured (coarse texture) soils are known to have high bulk density values between 1.6 and $1.8 \mathrm{~g} \mathrm{~cm}^{-3}$. Hence, reports from both field and laboratory studies have shown bulk densities to have contrasting results to surface areas of biochar-amended soils. [29], [24] and [23] reported that application of biochar can decrease the bulk density of soils. [29] showed in a soil column incubation study that biochar-amended soil columns had significantly lower bulk density than no-biochar controls. [16] reported that biochar-amended column had a lower rate of compaction compared to the control or manure-amended soil columns when all the columns were subjected to compaction by gravity and periodical leaching events. They further stated that the decrease in bulk density of biochar-amended soil could be one of the indicators of the improvement of soil structure or aggregation and aeration, and could be soil-specific. 


\begin{tabular}{|c|c|c|c|c|c|}
\hline Soil types & Biochar type & Study type (scale) & $\begin{array}{l}\text { Rate of biochar } \\
\text { application }\end{array}$ & Bulk density & Reference \\
\hline & & & $\%\left(\mathrm{~g} \mathrm{~g}^{-1}\right)$ & $\mathrm{g} \mathrm{cm}^{-3}$ & \\
\hline \multirow[t]{2}{*}{$\begin{array}{l}\text { Norfolk loamy } \\
\text { sand: E }\end{array}$} & $\begin{array}{c}\text { Pecan (Carya } \\
\text { illinoinensis) shells, } \\
700^{\circ} \mathrm{C}\end{array}$ & Laboratory & 0 & 1.52 & [32] \\
\hline & & & 2.1 & $1.45^{1}, 1.52^{2}$ & \\
\hline \multirow{2}{*}{$\begin{array}{l}\text { Norfolk loamy } \\
\text { sand: E and Bt }\end{array}$} & & & 0 & 1.34 & \\
\hline & & & 2.1 & $1.36^{1}, 1.34^{2}$ & \\
\hline \multirow[t]{4}{*}{$\begin{array}{c}\text { Hydroagric stagnic } \\
\text { anthrosol }\end{array}$} & $\begin{array}{c}\text { Wheat (Triticum spp.) } \\
\text { straw, } 350-550^{\circ} \mathrm{C}\end{array}$ & Field & 0 & $0.99,0.94^{3}$ & [63] \\
\hline & & & 1.1 & $0.96,0.91^{3}$ & \\
\hline & & & 2.2 & $0.91,0.86^{3}$ & \\
\hline & & & 4.4 & $0.89,0.88^{3}$ & \\
\hline \multirow[t]{3}{*}{ Residue sand } & $\begin{array}{c}\text { Municipal green } \\
\text { waste }, 450^{\circ} \mathrm{C}\end{array}$ & Laboratory & 0 & 1.65 & [24] \\
\hline & & & 2.6 & 1.55 & \\
\hline & & & 5.2 & 1.44 & \\
\hline \multirow[t]{4}{*}{ Clarion fine loamy } & $\begin{array}{l}\text { Mixed hardwoods, } \\
\qquad 500^{\circ} \mathrm{C}\end{array}$ & Laboratory & 0 & $1.21,1.34^{4}$ & [29] \\
\hline & & & 0.5 & $1.10,1.24^{4}$ & \\
\hline & & & 1.0 & $1.08,1.24^{4}$ & \\
\hline & & & 2.0 & $1.08,1.24^{4}$ & \\
\hline
\end{tabular}

Source: [16]. ${ }^{1}$ measured after 44 days; ${ }^{2}$ measured after 94 days; ${ }^{3}$ measured after 1 year; ${ }^{4}$ measured after 15 months.

Table 2. Soil bulk density as affected by biochar application

\subsubsection{Aggregate stability}

Results of studies showing biochar effect on soil aggregation are illustrated in Table 3. Studies have shown biochar to respond positively to aggregation. Though [16] reported that data on aggregate stability and penetration resistance of biochar-amended soils are scarce, a few studies generally showed that low-temperature $\left(220^{\circ} \mathrm{C}\right)$ hydrochar made from spent brewer's grains (a residue from beer brewing) responded positively to aggregation of Albic Luvisol by significantly increasing water-stable aggregates as compared to the control treatment. [31] have reported that the formation of complexes of biochar with minerals, as the result of interactions between oxidized carboxylic acid groups at the surface of biochar particles, should be responsible for the improved soil aggregate stability (Figure 2). As a result, soil aggregates 
and pore size distribution can be improved by adding organic matter from biodegradation and thus improving soil hydraulic properties. However, other authors have reported contrasting results. For instance, [32] reported that with or without mixing Bt and E horizons with pecan shell (Carya illinoinensis), biochar-amended soil decreased aggregation compared to the control, while [33] reported mixing of biochar from pecan with switchgrass increased aggregation, but the effect was however significantly lower when the soil was treated only with biochar without mixing with switchgrass. From this trend of results, [16] concluded that a positive effect on soil aggregate stability would require the presence of a substrate (i.e switchgrass) along with biochar as an amendment.

\subsubsection{Penetration resistance}

Studies on the effect of biochar amendment on soil penetration resistance are illustrated in Table 3. Penetration resistance measures the capacity of a soil in its confined state to resist penetration by a rigid object [34]. It is affected by moisture content. Thus, it affects the potential for root growth and development. Ehlers et al. [35] found root growth to be inversely related to penetration resistance. Results from literatures have shown that the effect of biochar application on soil penetration resistance is dependent on time of application. Busscher et al. [32] reported that mixing Norfolk loamy sand $\mathrm{E}$ and $\mathrm{E}$ and Bt layers with pecan shell biochar produced at a temperature of $700^{\circ} \mathrm{C}$ increased penetration resistance measured after 44 days of application. Penetration resistance was, however, reduced when measured after 96 days of application. Thus, soil compaction may not be alleviated by biochar addition over short period of time, but may be altered in the long run due to changes in properties as a result of aging of biochar.

\begin{tabular}{|c|c|c|c|c|c|c|}
\hline Soil types & Biochar type & $\begin{array}{c}\text { Study type } \\
\text { (Scale) }\end{array}$ & $\begin{array}{c}\text { Rate of biochar } \\
\text { application }\end{array}$ & Aggregation & $\begin{array}{c}\text { Penetration } \\
\text { resistance }\end{array}$ & Reference \\
\hline & & & $\%\left(\mathrm{~g} \mathrm{~g}^{-1}\right)$ & $\%$ & $\mathrm{MPa}$ & \\
\hline \multirow[t]{2}{*}{$\begin{array}{c}\text { Norfolk } \\
\text { loamy sand: } \\
\text { E }\end{array}$} & $\begin{array}{c}\text { Pecan shells, } \\
700^{\circ} \mathrm{C}\end{array}$ & Laboratory & 0 & 14.3 & $1.19^{1}, 0.80^{2}$ & [32] \\
\hline & & & 2.1 & 12.9 & $1.27^{1}, 0.88^{2}$ & \\
\hline \multicolumn{7}{|l|}{ Norfolk } \\
\hline \multirow{3}{*}{$\begin{array}{c}\text { loamy sand: } \\
\text { E and Bt }\end{array}$} & & & 0 & 27.3 & $0.71^{1}, 0.76^{2}$ & \\
\hline & & & & & & \\
\hline & & & 2.1 & 20.9 & $0.88^{1}, 0.94^{2}$ & \\
\hline \multirow[t]{3}{*}{$\begin{array}{c}\text { Norfolk } \\
\text { loamy sand: } \\
\text { Ap }\end{array}$} & $\begin{array}{c}\text { Pecan shells, } \\
700^{\circ} \mathrm{C}\end{array}$ & Laboratory & 0 & $9.95,13.0^{*}$ & $1.04^{1}, 1.1^{2}$ & [33] \\
\hline & & & 0.5 & $9.53,12.7^{*}$ & $0.96^{1}, 1.15^{2}$ & \\
\hline & & & 1.0 & $10.7,12.3^{*}$ & $1.03^{1}, 1.02^{2}$ & \\
\hline
\end{tabular}




\begin{tabular}{|c|c|c|c|c|c|c|}
\hline Soil types & Biochar type & $\begin{array}{c}\text { Study type } \\
\text { (Scale) }\end{array}$ & $\begin{array}{c}\text { Rate of biochar } \\
\text { application }\end{array}$ & Aggregation & $\begin{array}{c}\text { Penetration } \\
\text { resistance }\end{array}$ & Reference \\
\hline & & & 2.0 & $9.23,11.8^{*}$ & $0.82^{1}, 0.87^{2}$ & \\
\hline \multirow[t]{6}{*}{$\begin{array}{c}\text { Albic } \\
\text { Luvisol }\end{array}$} & $\begin{array}{c}\text { Hydrochar, } \\
220^{\circ} \mathrm{C}\end{array}$ & Laboratory & 0 & 49.8 & - & [64] \\
\hline & & & 5 & 69.0 & - & \\
\hline & & & 10 & 65.1 & - & \\
\hline & & Greenhouse & 0 & 10.3 & - & \\
\hline & & & 5 & 20.8 & - & \\
\hline & & & 10 & 33.8 & - & \\
\hline
\end{tabular}

Table 3. Soil aggregation and penetration resistance as affected by biochar application

\subsection{Hydrological properties}

Several authors have reported positive response of soil hydrological properties to biochar amendment. This may be due to the fact that soil hydrological properties such as infiltration rate, moisture content, hydraulic conductivity, water-holding capacity and water retention are invariably related to soil surface area, bulk density, porosity and aggregate stability [16]. In other words, an alteration in these soil physical properties as caused by biochar application would lead to a change in soil hydrological properties.

\subsubsection{Water-holding capacity, water retention and moisture content}

Table 4 shows the results of biochar application effect on water-holding capacity. The amount of water in a soil is a function of its ability to hold and retain water for plant use against the influence of gravity. Fine-textured soils would have higher moisture content at the same tension as soils with coarse particles. This is because the ability of a soil to retain water is a function of the micropores in the soil, which is usually lower in coarse-textured soils. Hence, moisture required by plants to upset the evapotranspirational demand of the atmosphere may be limiting, especially in coarse-textured soils. Thus, application of biochar can increase waterstorage ability of coarse-textured soils. Several studies have reported alterations in waterholding capacity and water retention in soils amended with biochar. [33] and [36] reported that $0.5 \%\left(\mathrm{~g} \mathrm{~g}^{-1}\right)$ biochar application rate was sufficient to improve water-holding capacity. Application of biochar produced from black locust (Robinia pseudoacacia) was reported to increase the available water capacity by $97 \%$, saturation water content by $56 \%$, but reduced hydraulic conductivity [25]. This can also influence soil aeration and temperature to a very large extent. [29] reported that results from a long-term column study indicated that biocharamended Clarion soil retained up to $15 \%$ more water, with $13 \%$ and $10 \%$ more water retention at $-100 \mathrm{KPa}$ and $-500 \mathrm{KPa}$ soil matric potential, respectively, compared to control (unamended soils). [37] showed that coal-derived humic acid substances can increase water retention, available water capacity and aggregate stability of inherently degraded soils. [38] reported that biochar application increased the available water capacity in sandy soil, with no effect on a 
loamy soil, and decreased moisture content in a clayey soil. [16] suggested that such response may be due to the hydrophobic nature of the charcoal that caused alterations in soil pore size distribution. [38], therefore, advised that because the soil moisture retention may only be improved in coarse-textured soils, a careful choice of biochar/soil combination needs to be taken into consideration.

\begin{tabular}{|c|c|c|c|c|c|}
\hline Soil types & Biochar type & Study type (Scale) & $\begin{array}{c}\text { Rate of biochar } \\
\text { application }\end{array}$ & $\begin{array}{l}\text { Water holding } \\
\text { capacity }\end{array}$ & Reference \\
\hline & & & $\%\left(\mathrm{~g} \mathrm{~g}^{-1}\right)$ & $\left(\mathrm{g} \mathrm{cm}^{-3}\right)$ & \\
\hline \multirow[t]{3}{*}{ Residue sand } & $\begin{array}{c}\text { Municipal green } \\
\text { waste, } 450^{\circ} \mathrm{C}\end{array}$ & Laboratory & 0 & 0.11 & [24] \\
\hline & & & 2.6 & 0.16 & \\
\hline & & & 5.2 & 0.20 & \\
\hline \multirow[t]{4}{*}{$\begin{array}{l}\text { Norfolk loamy } \\
\text { sand: Ap }\end{array}$} & Pecan shells, $700^{\circ} \mathrm{C}$ & Laboratory & 0 & 0.64 & [33] \\
\hline & & & 0.5 & 0.59 & \\
\hline & & & 1.0 & 0.60 & \\
\hline & & & 2.0 & 0.66 & \\
\hline \multirow[t]{4}{*}{ Sandy loam } & $\begin{array}{c}\text { Ponderosa pine } \\
\text { (Pinus ponderosa), } \\
450^{\circ} \mathrm{C}\end{array}$ & Laboratory & 0 & 11.9 & [36] \\
\hline & & & 0.5 & 12.4 & \\
\hline & & & 1.0 & 13.0 & \\
\hline & & & 5.0 & 18.8 & \\
\hline \multirow[t]{2}{*}{ Silt loam } & Birch, $400^{\circ} \mathrm{C}$ & Field & 0 & 0.49 & {$[62]$} \\
\hline & & & 1.2 & 0.54 & \\
\hline
\end{tabular}

Table 4. Soil water holding capacity as affected by biochar application

\subsection{Biochar and soil chemical properties}

Most studies of biochar as a soil amendment have focused majorly on soil nutrient status, taking into consideration cation exchange capacity, nutrient content, $\mathrm{pH}$, the carbon sequestration potential of the amended soil, and vegetative growth and yield of crops. Biochar has the potential to improve soil CEC due to the fact that it is often characterized by high CEC values, due to its negative surface charges and its high specific surface area as was reported for biochar produced from crop residues [39].

Furthermore, the immediate beneficial effect of biochar application on crop productivity in tropical soils may result from increase in availability of nitrogen, phosphorus, potassium, 
calcium, copper and zinc as reported for soils amended with secondary forest biochar [40]. Also, poultry litter biochar may result in strong increase in soil extractable phosphorus [41] when incorporated into the soil. In evaluating the effect of different biochars on soil chemical properties, [42] reported that biochar produced from poultry manure had higher electrical conductivity, nitrogen, phosphorus and $\mathrm{pH}$ values than that of garden waste. However, this may be due to their effects in reducing leaching and fixation of nutrients as moderate biochar additions are not a direct supplier of plant nutrients in the long-term.

\subsection{Effects of biochar application on Soil Organic Carbon (SOC)}

Biochar application can directly or indirectly affect SOC dynamics. Indirectly, biochar could affect net primary production and, thus, the amount of biomass that may remain in agroecosystems. This would result to alteration in soil carbon inputs. [8] stated that higher belowground net primary production and increased root-derived carbon inputs after biochar application may particularly result in an increase in SOC.

Directly, biochar can inhibit degradation process, and as a result increase the mean residence time (MRT) of SOC (i.e. the mean time that a SOC-carbon atom spends in soil). As a direct consequence, biochar application would enhance SOC stabilization processes and contribute to SOC sequestration. The MRT of biochar-carbon is thought by some to be in the range of millennia [43]. However, information on biochar longevity in soil is meagre and varies between biochars and sites. For example, the MRTs of biochar in field experiments ranged from about 8 years for biochar produced by burning of forest trees during slash-and-burn agricultural practices [44] to 3,600 years for biochar produced from prunings of old mango (Mangifera indica L.) trees [45]. Also, biochar longevity in soil may be affected by differences in climatic conditions. For example, chemical and/or biological mineralization of natural chars produced from wood during bushfires was slower under Mediterranean climate when compared to temperate climates in Australia [46].

\subsection{Liming effect}

Biochar can be said to be acidic or alkaline in nature depending on the temperature of the materials used during pyrolysis. [47] explained that the acid functional group concentration in biochars produced from the biomass of rice, valley oak (Quercus lobata $\mathrm{Ne}^{\prime} e$ ), etc decreased with increasing peak pyrolysis temperature as more fused aromatic ring structures were produced and more volatile matter was lost. The effectiveness of both types will depend on the $\mathrm{pH}$ of the soil to be amended. [48] stated that the alkaline biochars produced at higher pyrolysis temperature are more effective in supporting increases in biomass by improved growth conditions than acidic biochars presumably through increases in soil alkalinity. [49] stated that the moderation in aluminium toxicity may be the reason why biochar application has positive effects on productivity in tropical and irrigated systems on highly weathered and acid soils with low-activity clays. This is because the reduction of aluminium and iron concentrations in the soil solution will enhance the availability of previously bound phosphorus to plants, and plant roots would be able to explore even acid soils to absorb nutrients and water more effectively. 


\subsection{Effect of biochar on soil microorganisms}

Studies have shown higher microbial biomass but yet lower microbial activity in biocharamended soil than the neighbouring soils [50]. However, most studies have focused on biochar interaction with mycorrhizal fungi [50]. Specifically, biochar has been reported to have symbiotic relationship with the mycorrhizal system. According to [51], the four mechanisms by which biochar could improve mycorrhizal abundance (40\%) and functioning are listed as follows:

i. Alteration of soil physico-chemical properties,

ii. Indirect effects on mycorrhizae through effects on other soil microbes,

iii. Plant-fungus signalling interference, and

iv. Detoxification of allelochemicals on biochar.

[52] noted $50 \%$ to $72 \%$ increase in soil biological nitrogen fixation through biochar application. [53] have hypothesized both bacteria and fungi to be better protected from grazers or competitors by exploring pore habitats in biochars. This is because biochar provides microbial habitat and refugia for microbes where they are also protected from unfavourable conditions.

\subsection{Effect of biochar on crop yield}

The summary of experiments assessing the impact of biochar addition on crop yield is showed in Table 5. From the agricultural perspective, the summary of the effect of biochar in regulating soil hydrological, physical and chemical properties results to improved soil productivity and consequently increased crop yield. However, the effect of biochar on soil health as well as crop productivity can be influenced by the forms (dust, fine particles, coarse grain) and the methods of application (surface application, top dressing, drilling) of biochar to soil. [54] clearly explained that even small quantities of biochar added to seed coatings may in some cases be sufficient for a beneficial effect.

[40] reported increasing crop yields with increasing biochar applications of up to $140 \mathrm{t}$ carbon ha ${ }^{-1}$ on highly weathered soils in the humid tropics. Also, [55] found that the biomass growth of beans rose with biochar applications up to $60 \mathrm{t}$ carbon ha ${ }^{-1}$. Furthermore, scientists have reported that application of biochar on soil has significant effect on net primary crop production, grain yield and dry matter production [56,57,58,59].

\begin{tabular}{lll}
\hline Author & Study outline & Results summary \\
\hline$[65]$ & Cowpea on xanthic ferralsol & Char at $67 \mathrm{t} /$ ha increased biomass by \\
& $150 \%$ \\
& Char at $135 \mathrm{t} /$ ha increased biomass by \\
& $200 \%$
\end{tabular}




\begin{tabular}{|c|c|c|}
\hline Author & Study outline & Results summary \\
\hline [40] & $\begin{array}{l}\text { Soil fertility and nutrient retention. } \\
\text { Cowpea was planted in pots and rice } \\
\text { crops in lysimeters, Brazil }\end{array}$ & $\begin{array}{l}\text { Biochar additions significantly } \\
\text { increased biomass production by } 38 \% \text { to } \\
45 \% \text { (no yield reported) }\end{array}$ \\
\hline [66] & $\begin{array}{l}\text { Comparison of maize yields between } \\
\text { disused charcoal production sites and } \\
\text { adjacent fields, Ghana }\end{array}$ & $\begin{array}{l}\text { Grain and biomass yield was } 91 \% \text { and } \\
44 \% \text { higher on charcoal site than control }\end{array}$ \\
\hline [67] & $\begin{array}{l}\text { Maize, cowpea and peanut trial in area } \\
\text { of low soil fertility }\end{array}$ & $\begin{array}{l}\text { Acacia bark charcoal plus fertilizer } \\
\text { increased maize and peanut yields (but } \\
\text { not cowpea) }\end{array}$ \\
\hline [42] & $\begin{array}{l}\text { Pot trial on radish yield in heavy soil } \\
\text { using commercial green waste biochar } \\
\text { (three rates) with and without nitrogen }\end{array}$ & $\begin{array}{l}\text { Biochar at } 100 \mathrm{t} / \mathrm{ha} \text { increased yield } \times 3 \text {; } \\
\text { linear increase } 10 \text { to } 50 \mathrm{t} / \mathrm{ha} \text {, but no } \\
\text { effect without added nitrogen }\end{array}$ \\
\hline
\end{tabular}

Source: [16].

Table 5. Summary of experiments assessing the impact of biochar addition on crop yield

\section{Conclusion}

Biochar, as an amendment on soil physical, chemical and biological properties, depends on environmental conditions, dynamic properties of soils, biochar properties which are a function of the organic materials and conditions used for biochar production and the rate and method of application.

Notable soil physical properties found to be enhanced by biochar include soil surface area, bulk density, porosity, aggregate stability, penetration resistance and moisture content. Also, soil $\mathrm{pH}$, organic carbon and cation exchange capacity were enhanced in biochar-amended soils. Biologically, mycorrhizal abundance, biological nitrogen fixation, microbial biomass and microbial habitats were improved in biochar-amended soils compared to unamended soils.

Modification of soil physical, chemical and biological properties by biochar application resulted to improved plant nutrient retention, acquisition and availability, leading to improved biomass growth, dry matter production and crop yields.

\section{Author details}

Suarau O. Oshunsanya and OrevaOghene Aliku

*Address all correspondence to: soshunsanya@yahoo.com

Department of Agronomy, University of Ibadan, Ibadan, Nigeria 


\section{References}

[1] Woods WI. Slash and Char. In: Balance Carbon and Restore Soil Fertility [Internet]. 2003 [Updated: 2006]. Available from: www.biochar.org [Accessed: 2 March, 2015]

[2] Lehmann J, Gaunt J, Rondon M. Bio-char sequestration in terrestrial ecosystems - a review. Mitig Adapt Strategies Glob Change. 2006;11:395-419.

[3] Fagbenro JA, Oshunsanya SO, Oyeleye BA. Effects of gliricidia biochar and inorganic fertilizer on moringa plant grown in an oxisol. Commun Soil Sci Plant Analysis 2015;46(5):619-26.

[4] Anders E, Watzinger A, Rempt F, Kitzler B, Wimmer B, Zehetner F, et al. Biochar affects the structure rather than the total biomass of microbial communities in temperate soils. Agri Food Sci 2013;22:404-23.

[5] Seifritz W. Should we store carbon in charcoal? Int J Hydrogen Energy 1993;18:405-7.

[6] Lehmann J, Joseph S. Biochar for Environmental Management: Science and Technology. London: Earthscan; 2009.

[7] Glaser B, Haumaier L, Guggenberger G, Zech W. The 'terra preta' phenomenon: a model for sustainable agriculture in the humid tropics. Naturwissenschaften 2001;88:37-41.

[8] Sohi S, Krull E, Lopez-Capel E, Bol R. A review of biochar and its use and function in soil. Adv Agron 2010;105:47-82.

[9] Krishnakumar S, Kumar SR, Mariappan N, Surendar KK. Biochar-boon to soil health and crop production. Afr J Agri Res 2013;8(38):4726-39.

[10] Krull ES, Swanston CW, Skjemstad JO, McGowan JA. Importance of charcoal in determining the age and chemistry of organic carbon in surface soils. J Geophys Res. 2006;P. 111 G04001DOI: doi:10.1029/2006JG000194

[11] Mukherjee A. Physical and Chemical Properties of a Range of Laboratory-produced Fresh and Aged Biochars [thesis]. Gainesville, FL, USA: University of Florida; 2011.

[12] Mukherjee A, Zimmerman AR, Harris WG. Surface chemistry variations among a series of laboratory-produced biochars. Geoderma 2011;163:247-55.

[13] Zimmerman AR. Abiotic and microbial oxidation of laboratory-produced black carbon (biochar). Environ Sci Technol 2010;44:1295-301.

[14] Sweatman MB, Quirke N. Characterization of porous materials by gas adsorption: Comparison of nitrogen at $77 \mathrm{k}$ and carbon dioxide at $298 \mathrm{k}$ for activated carbon. Langmuir 2001;17:5011-20. 
[15] Jagiello J, Thommes M. Comparison of DFT characterization methods based on N2, $\mathrm{Ar}, \mathrm{CO} 2$, and $\mathrm{H} 2$ adsorption applied to carbons with various pore size distributions. Carbon 2004;42:1227-32.

[16] Mukherjee A, Lal R. Biochar impacts on soil physical properties and greenhouse gas emissions. Agronomy 2013;3:313-39.

[17] Atkinson CJ, Fitzgerald JD, Hipps NA. Potential mechanisms for achieving agricultural benefits from biochar application to temperate soils: a review. Plant Soil 2010;337:1-18.

[18] Fernandes MB, Skjemstad JO, Johnson BB, Wells JD, Brooks P. Characterization of carbonaceous combustion residues. In: Morphological, elemental and spectroscopic features. Chemosphere 2003;51:785-95.

[19] Schmidt MWI, Noack AG. Black carbon in soils and sediments: analysis, distribution, implications, and current challenges. Glob Biogeochem Cycles. 2000;14:777-93.

[20] Hammes K, Torn MS, Lapenas AG, Schmidt MWI. Centennial black carbon turnover observed in a Russian steppe soil. Biogeosciences 2008;5:1339-50.

[21] Skjemstad JO, Taylor JA, Janik LJ, Marvanek SP. Soil organic carbon dynamics under long-term sugarcane monoculture. Aust J Soil Res 1999;37:151-64.

[22] Verheijen F, Jeffery S, Bastos AC, Van der Velde M, Diafas I. Biochar Application to Soils: A Critical Scientific Review of Effects on Soil Properties, Processes and Functions. JRC Scient. Technical reports. 2010; 1-166.

[23] Chen H-X, Du Z-L, Guo W, Zhang Q-Z. Effects of biochar amendment on cropland soil bulk density, cation exchange capacity, and particulate organic matter content in the North China plain. Yingyong Shengtai Xuebao. 2011;22:2930-4.

[24] Jones BEH, Haynes RJ, Phillips IR. Effect of amendment of bauxite processing sand with organic materials on its chemical, physical and microbial properties. J Environ Manag 2010;91:2281-8.

[25] Uzoma KC, Inoue M, Andry H, Zahoor A, Nishihara E. Influence of biochar application on sandy soil hydraulic properties and nutrient retention. J Food Agric Environ 2011;9:1137-43.

[26] Van Zwieten L, Singh B, Joseph S, Kimber S, Cowie A, Yin Chan K. Biochar and emissions of non- $\mathrm{CO}_{2}$ greenhouse gases from soil. In: Lehmann J, Joseph S. (eds.) Biochar for Environmental Management. VA, USA: Earthscan: London Sterling; 2009.

[27] Hammes K, Schmidt, M. Changes in biochar in soil. In: Lehmann J, Joseph S. (eds.) Biochar for Environmental Management: Science and Technology. London, UK: Earthscan: 2009. pp. 169-182.

[28] Liang B, Lehmann J, Solomon D, Kinyangi J, Grossman J, O'Neill B, et al. Black carbon increases cation exchange capacity in soils. Soil Sci Soc Am J 2006;70:1719-30. 
[29] Laird DA, Fleming P, Davis DD, Horton R, Wang BQ, Karlen DL. Impact of biochar amendments on the quality of a typical midwestern agricultural soil. Geoderma 2010;158:443-9.

[30] Oshunsanya SO. Soil Physics. 1st ed. Nigeria: Dabank Publishers; 2011. 166 p.

[31] Glaser B, Lehmann J, Zech W. Ameliorating physical and chemical properties of highly weathered soils in the tropics with charcoal - a review. Biol Fert Soils 2002;35:219-30.

[32] Busscher WJ, Novak JM, Ahmedna M. Physical effects of organic matter amendment of a southeastern us coastal loamy sand. Soil Sci 2011;176:661-7.

[33] Busscher WJ, Novak JM, Evans DE, Watts DW, Niandou MAS, Ahmedna M. Influence of pecan biochar on physical properties of a norfolk loamy sand. Soil Sci 2010;175:10-4.

[34] Soil Survey Division Staff. Soil Survey Manual. Washington, D.C.: USDA-NRCS; 1993.

[35] Ehlers W, Popke V, Hesse F, Bohm W. Penetration resistance and root growth of oats in tilled and untilled loam soil. Soil Tillage Res 1983;3:261-75.

[36] Briggs C, Breiner JM, Graham RC. Physical and chemical properties of pinus ponderosa charcoal: implications for soil modification. Soil Sci 2012;177:263-8.

[37] Minamikawa K, Hayakawa A, Nishimura S, Akiyama H, Yagi K. Comparison of indirect nitrous oxide emission through lysimeter drainage between an andosol upland field and a fluvisol paddy field. Soil Sci Plant Nutr 2011;57:843-54.

[38] Tryon EH. Effect of charcoal on certain physical, chemical, and biological properties of forest soils. Ecol Monogr 1948;18:81-115.

[39] Yuan JH, Xu RK, Zhang H. The forms of alkalis in the biochar produced from crop residues at different temperatures. Biores Technol 2011;102:3488-97.

[40] Lehmann J, da Silva JP, Steiner C, Nehls T, Zech W, Glaser B. Nutrient availability and leaching in an archaeological anthrosol and a ferralsol of the Central Amazon basin: fertilizer, manure and charcoal amendments. Plant Soil 2003;249:343-57.

[41] Novak JM, Busscher WJ, Laird DA, Ahmedna M, Watts DW, Niandou MAS. Impact of biochar amendment on fertility of a Southeastern coastal plain soil. Soil Sci 2009;174:10512.

[42] Chan KY, Van Zwieten L, Meszaros I, Downie A, Joseph S. Assessing the agronomic values of contrasting char materials on an Australian hard setting soil. In: International Agrichar Initiative (IAI); 27 April-2 May 2007; Terrigal, New South Wales. Australia: 2007. 
[43] Glaser B, Birk JJ. State of the scientific knowledge on properties and genesis of Anthropogenic Dark Earths in Central Amazonia (terra preta de I'ndio). Geochim Cosmochim Ac 2013;82:39-51.

[44] Nguyen BT, Lehmann J, Kinyangi J, Smernik R, Riha SJ, Engelhard MH. Long-term black carbon dynamics in cultivated soil. Biogeochemistry 2008;89:295-308.

[45] Major J, Rondon M, Molina D, Riha SJ, Lehmann J. Maize yield and nutrition after 4 years of doing biochar application to a Colombian savanna oxisol. Plant Soil 2010;333:117-28.

[46] McBeath AV, Smernik RJ, Krull ES. A demonstration of the high variability of chars produced from wood in bushfires. Org Geochem 2013;55:38-44.

[47] Li X, Shen Q, Zhang D, Mei X, Ran W, Xu Y, et al. Functional groups determine biochar properties ( $\mathrm{pH}$ and EC) as studied by two-dimensional 13C NMR correlation spectroscopy. PLoS ONE 2013;8DOI: DOI: 10.1371/journal.pone.0065949

[48] Biederman LA, Harpole WS. Biochar and its effects on plant productivity and nutrient cycling: a meta-analysis. GCB Bioenerg 2013;5:202-14.

[49] Blackwell P, Riethmuller G, Collins M. Biochar application to soil (Chapter 12). In: Lehmann J, Joseph S. (eds.) Biochar for Environmental Management: Science and Technology. London, UK: Earthscan; 2009. p. 207.

[50] Thies JE, Rillig M. Characteristics of biochar: biological properties. In: Lehmann J, Joseph S. (eds.) Biochar for Environmental Management: Science and Technology. London: Earthscan; 2009. pp. 85-105.

[51] Warnock DD, Lehmann J, Kuyper TW, Rillig MC. Mycorrhizal responses to biochar in soil-concepts and mechanisms. Plant Soil 2007;300:9-20.

[52] Lehmann J, Rondon M. Biochar soil management on highly weathered soils in the humid tropics. In: Uphoff N, et al. (eds.) Biological Approaches to Sustainable Soil Systems. Boca Raton, FL: CRC Press; 2006. pp. 517-30.

[53] Saito M, Marumoto, T. Inoculation with arbuscular mycorrhizal fungi: the status quo in Japan and the future prospects. Plant Soil 2002;244:273-9.

[54] Hill RA, Harris A, Stewart A, Bolstridge N, McLean KL, Blakeley R. Charcoal and selected beneficial microorganisms: plant trials and SEM observations. In: International Agrichar Conference; 2007; Terrigal May. NSW Australia: 2007.

[55] Rondon M, Lehmann J, Ramirez J, Hurtado M. Biological nitrogen fixation by common beans (Phaseolus vulgaris L.) increases with biochar additions. Biol Fertil Soils 2007;43:688-708.

[56] Chan Y, Van Zwieten L, Meszaros I, Downie A, Joseph S. Using poultry litter biochars as soil amendments. Austr J Soil Res 2008;46:437-44. 
[57] Chan KY, Xu Z. Biochar: nutrient properties and their enhancement. In: Lehmann J, Joseph S. (eds.) Biochar for environmental management. Science and Technology, London: Earthscan; 2009. pp. 67-84.

[58] Major J, Steiner C, Downie A, Lehmann J. Biochar effects on nutrient leaching. In: Lehmann J, Joseph S. (eds.) Biochar for environmental management. Science and Technology. London: Earthscan ; 2009. pp. 271-287.

[59] Spokas KA, Reicosky DC. Impacts of sixteen different biochars on soil greenhouse gas production. Ann Environ Sci 2009;3:179-93.

[60] Anderson PS, McLaughlin H. Biochar basics: an introduction about the "what and why" of biochar. In: Northeast Biochar Symposium; 2009; USA. University of Massachussetts Amherst: 2009.

[61] Dempster DN, Gleeson DB, Solaiman ZM, Jones DL, Murphy DV. Decreased soil microbial biomass and nitrogen mineralisation with eucalyptus biochar addition to a coarse textured soil. Plant Soil 2012;354:311-24.

[62] Karhu K, Mattila T, Bergstro ${ }^{\circ} \mathrm{m}$ I, Regina K. Biochar addition to agricultural soil increased $\mathrm{CH}_{4}$ uptake and water holding capacity - results from a short-term pilot field study. Agric Ecosyst Environ 2011;140:309-13.

[63] Mankasingh U, Choi PC, Ragnarsdottir V. Biochar application in a tropical, agricultural region: a plot scale study in Tamil Nadu, India. Appl Geochem 2011;26:S218-21.

[64] George C, Wagner M, Kucke M, Rillig MC. Divergent consequences of hydrochar in the plant-soil system: Arbuscular mycorrhiza, nodulation, plant growth and soil aggregation effects. Appl Soil Ecol 2012;59:68-72.

[65] Glaser B, Lehmann J, Zech W. Ameliorating physical and chemical properties of highly weathered soils in the tropics with charcoal - a review. Biol Fertil Soils 2002;35:219-30.

[66] Oguntunde PG, Fosu M, Ajayi AE, Van de Giesen N. Effects of charcoal production on maize yield, chemical properties and texture of soil. Biol Fertil Soils 2004;39:295-9.

[67] Yamamoto M, Okimori Y, Wibowo IF, Anshori S, Ogawa M. Effects of the application of charred bark of Acacia mangium on the yield of maize, cowpea and peanut, and soil chemical properties in South Sumatra, Indonesia. Soil Sci Plant Nutr 2006;52:489-95. 
